\title{
Protocol
}

\section{Isolation of Chloroplasts from Plant Protoplasts}

\author{
Shiu-Cheung Lung, ${ }^{1}$ Matthew D. Smith, ${ }^{2}$ and Simon D.X. Chuong ${ }^{3,4}$ \\ ${ }^{1}$ School of Biological Sciences, University of Hong Kong, Pokfulam, Hong Kong SAR, China; ${ }^{2}$ Department \\ of Biology, Wilfrid Laurier University, Waterloo, Ontario N2L 3C5, Canada; ${ }^{3}$ Department of Biology, University \\ of Waterloo, Waterloo, Ontario N2L 3G1, Canada
}

Chloroplasts can be isolated from higher plants directly following homogenization; however, the resulting yield, purity, and intactness are often low, necessitating a large amount of starting material. This protocol is optimized to produce a high yield of pure chloroplasts from isolated Arabidopsis protoplasts. The two-part method is a simple, scaled-down, and low-cost procedure that readily provides healthy mesophyll protoplasts, which are then ruptured to release intact chloroplasts. Chloroplasts isolated using this method are competent for use in biochemical, cellular, and molecular analyses.

It is essential that you consult the appropriate Material Safety Data Sheets and your institution's Environmental Health and Safety Office for proper handling of equipment and hazardous materials used in this protocol.

RECIPES: Please see the end of this protocol for recipes indicated by $<R>$. Additional recipes can be found online at http://cshprotocols.cshlp.org/site/recipes.

\section{Reagents}

Arabidopsis thaliana ecotype Columbia (3- to 4-wk-old plants)

Sow stratified seeds onto moistened potting soil containing a 1:1 mixture of Sunshine LC1 and LG3 mixes. Maintain plants in a growth chamber with a 12 -h photoperiod at $22^{\circ} \mathrm{C}$ and a photon flux intensity of $100 \mu \mathrm{mol} / \mathrm{m}^{2} / \mathrm{sec}$.

CS-sucrose buffer $<\mathrm{R}>$

Enzyme buffer for protoplasts, freshly prepared $<\mathrm{R}>$

Fluorescein diacetate $(10 \mu \mathrm{g} / \mathrm{mL}$; optional; see Step 11)

HEPES-sorbitol buffer $<\mathrm{R}>$

Percoll gradient buffer $(40 \%$; ice-cold $)<\mathrm{R}>$

Percoll gradient buffer ( $85 \%$; ice-cold) $<\mathrm{R}>$

W5 solution for protoplasts $<\mathrm{R}>$

Equipment

Centrifuge (refrigerated tabletop, with swinging-bucket rotor)

Compound microscope

Conical tubes (15- and 50-mL)

\footnotetext{
${ }^{4}$ Correspondence: schuong@uwaterloo.ca

(C) 2015 Cold Spring Harbor Laboratory Press

Cite this protocol as Cold Spring Harb Protoc; doi:10.1101/pdb.prot074559
} 
S.-C. Lung et al.

Cover glasses

Dental baseplate wax (Nu-Base)

Depression slides

Flat-tip forceps

Microcentrifuge tubes (0.5-, 1.5- and 2-mL)

Neubauer hemocytometer

Nylon mesh $(10-\mu \mathrm{m})$

In the following method, isolated protoplasts are ruptured using 10- $\mu$ m nylon mesh; chloroplasts, but not protoplasts, are small enough to pass through mesh of this size.

Nylon mesh $(75-\mu \mathrm{m})$

Pasteur pipettes

Petri dishes (100-mm)

Razor blades (double-sided)

Before use (Step 2), snap new double-sided razor blades in half before removing the paper covering.

Syringe (1-mL)

Vacuum pump

\section{METHOD}

The following protocol was adapted from Smith et al. (2003), Yoo et al. (2007), and Lung and Chuong (2012).

1. Harvest 30 well-expanded leaves from 3- to 4-wk-old Arabidopsis plants.

2. Cut the leaves into 0.5- to 1-mm strips using one half of a double-sided razor blade on a dental wax pad. To avoid tissue crushing at the cutting site, draw the blade over the surface of the leaf in a smooth motion. Move to a new area of the blade or switch to a new blade after cutting four to five leaves.

3. Transfer the leaf strips to $10 \mathrm{~mL}$ of enzyme buffer in a Petri dish. Dip both sides of the leaf strips in buffer using a pair of flat-tip forceps and vacuum infiltrate for $15 \mathrm{~min}$.

The ratio of enzyme solution to tissue is important; there should be sufficient liquid to cover the leaf strips without affecting the final enzyme concentrations.

4. Digest the leaf strips in enzyme buffer at room temperature in the dark for $3 \mathrm{~h}$ or longer without shaking. Check the release of protoplasts into solution regularly under a microscope. Avoid swirling the tissue during the digestion step, as protoplasts are less stable upon release into the medium.

The enzyme solution should turn green after a gentle swirl at the end of the digestion period.

5. After the digestion period, transfer a sample of the suspension to a depression slide and add a cover glass. Check the health of the released protoplasts under a microscope.

Healthy protoplasts are spherical and possess uniformly distributed chloroplasts throughout the cell, whereas unhealthy protoplasts often display chloroplast clumping and have an irregular shape.

6. Filter the enzyme-protoplast suspension through $75-\mu \mathrm{m}$ nylon mesh into a 50-mL tube. Allow the suspension to run down the inside of the tube to avoid splashing. Rinse the Petri dish with $10 \mathrm{~mL}$ of W5 solution and filter into the same $50-\mathrm{mL}$ tube.

The 75- $\mu$ m nylon mesh will allow the passage of protoplasts but retain the leaf material. The total volume of the filtered protoplast suspension should be $\sim 20 \mathrm{~mL}$.

7. Divide the protoplasts into two $15-\mathrm{mL}$ tubes and collect the protoplasts by centrifugation at $100 \mathrm{~g}$ for $2 \mathrm{~min}$ at $4^{\circ} \mathrm{C}$ using a swinging-bucket rotor in a tabletop centrifuge. 
8. Carefully remove and discard the supernatant with a Pasteur pipette without disturbing the loosely packed protoplast pellet. Resuspend each protoplast pellet in $10 \mathrm{~mL}$ of CS-sucrose buffer by gentle swirling.

The protoplasts will readily resuspend by gentle swirling. Do not resuspend by pipetting.

9. Centrifuge the protoplast suspension at $100 \mathrm{~g}$ for $2 \mathrm{~min}$ at $4{ }^{\circ} \mathrm{C}$ using a swinging-bucket rotor in a tabletop centrifuge.

Unhealthy protoplasts will settle to the lower half of the solution and cellular debris will form a pellet. Intact, healthy protoplasts will remain suspended in the upper layer.

10. Remove and discard the bottom half of the solution and the pellet using a Pasteur pipette without disturbing the upper layer of healthy protoplasts.

Removal of the unwanted protoplasts and cell debris using a Pasteur pipette will minimize the disturbance of the healthy protoplasts near the top of the supernatant.

11. Dilute the healthy protoplasts with $1 \mathrm{~mL}$ of $\mathrm{W} 5$ solution. Allow the solution to gently run down the side of the tube and mix by gentle swirling.

The viability of protoplasts can be determined by incubation in $10 \mu \mathrm{g} / \mathrm{mL}$ fluorescein diacetate.

12. Incubate the diluted healthy protoplasts on ice for $30 \mathrm{~min}$. During incubation, check the cell number using a hemocytometer.

The protoplasts should settle to the bottom of the tube during incubation.

13. Remove and discard the supernatant with a Pasteur pipette without disturbing the settled protoplasts. Carefully resuspend the protoplasts in $600 \mu \mathrm{L}$ of HEPES-sorbitol buffer.

Alternatively, protoplasts to be used for transfection experiments should be resuspended in stabilization buffer to a final concentration of 200,000 protoplasts/mL (Lung and Chuong 2012).

Isolating Chloroplasts

14. Fill the barrel of the syringe of an assembled protoplast rupturing device with the resuspended protoplasts. Pass them through the rupturing device into a $1.5-\mathrm{mL}$ tube.

To assemble a protoplast-rupturing device, cut off the tip of a 1-mL syringe. Cut off the bottom of a 0.5- $\mathrm{mL}$ microcentrifuge tube. Assemble the device by placing a $1.5 \times 1.5-\mathrm{cm}^{2}$ piece of $10-\mu \mathrm{m}$ nylon mesh between the syringe barrel and the top part of the centrifuge tube. One device can rupture up to 60,000 protoplasts without causing the mesh to clog. Multiple rupturing devices are recommended if larger numbers of protoplasts are to be lysed.

15. Prepare a $0.5-\mathrm{mL}$ discontinuous ice-cold Percoll gradient by carefully overlaying $0.25 \mathrm{~mL}$ of $40 \%$ Percoll gradient buffer on top of $0.25 \mathrm{~mL}$ of $85 \%$ Percoll gradient buffer in a 2-mL tube, being careful not to let the layers mix.

16. Layer the lysed protoplast solution over the Percoll gradient. Centrifuge at $2000 \mathrm{~g}$ for $10 \mathrm{~min}$ at $4^{\circ} \mathrm{C}$ using a swinging-bucket rotor in a tabletop centrifuge.

After centrifugation, intact chloroplasts should form a green band at the interface between the $40 \%$ and $85 \%$ layers. Broken chloroplasts will form a second green band in the $40 \%$ Percoll layer above the intact chloroplast layer. Soluble components released from broken chloroplasts will remain in the supernatant layer above the $40 \%$ Percoll.

17. Carefully aspirate and discard the supernatant, the upper layer of $40 \%$ Percoll, and the bottom layer of $85 \%$ Percoll. Aspirate only to within $0.5 \mathrm{~cm}$ of the green band at the interface of the Percoll layers to avoid disturbing the intact chloroplasts.

18. Dilute the intact chloroplasts from the interface of the Percoll layers by adding 8 volumes of HEPES-sorbitol buffer.

19. Pellet the chloroplasts by centrifuging at $750 \mathrm{~g}$ for $5 \mathrm{~min}$ at $4^{\circ} \mathrm{C}$ using a swinging-bucket rotor in a tabletop centrifuge.

20. Remove and discard the supernatant. Resuspend the chloroplast pellet in $50 \mu \mathrm{L}$ of HEPESsorbitol buffer.

Intact chloroplasts can be used immediately or stored at $-80^{\circ} \mathrm{C}$ indefinitely. 
S.-C. Lung et al.

Chloroplasts belong to a class of organelles found in plant and algae cells called plastids. Chloroplasts perform many important functions, including photosynthesis, amino acid and lipid biosynthesis, and nitrogen and sulfur assimilation (Keeling 2004). The majority of proteins involved in these metabolic processes are encoded by the nuclear genome, translated in the cytoplasm, and selectively targeted and imported into specific chloroplast subcompartments (Cline and Henry 1996).

In contrast to isolation of chloroplasts directly following homogenization (Fitzpatrick and Keegstra, 2001; Smith et al. 2003), the method described here produces a high yield of competent chloroplasts from isolated healthy protoplasts. Chloroplasts obtained using this method can be used for subsequent studies involving transient gene expression via polyethylene glycol-mediated transfection, in vitro chloroplast protein import assays (e.g., as described by Smith et al. 2003 and Lung and Chuong 2012), or chloroplast fractionation experiments.

\section{RECIPES}

\section{CS-Mannitol Buffer}

0.4 m mannitol

$20 \mathrm{~mm}$ 2-( $N$-morpholino)ethanesulfonic acid-KOH (pH 5.7)

$20 \mathrm{~mm} \mathrm{KCl}$

\section{CS-Sucrose Buffer}

$0.4 \mathrm{M}$ sucrose

$20 \mathrm{~mm}$ 2-( $\mathrm{N}$-morpholino)ethanesulfonic acid-KOH (pH 5.7)

$20 \mathrm{~mm} \mathrm{KCl}$

\section{Enzyme Buffer for Protoplasts}

1. Incubate CS-mannitol buffer at $70^{\circ} \mathrm{C}$ for $10 \mathrm{~min}$.

2. Cool buffer to $55^{\circ} \mathrm{C}$ before adding $1.5 \%(\mathrm{w} / \mathrm{v})$ cellulase and $0.4 \%(\mathrm{w} / \mathrm{v})$ macerozyme.

3. Incubate buffer at $55^{\circ} \mathrm{C}$ for $10 \mathrm{~min}$.

4. Cool buffer to room temperature before adding $0.1 \%(\mathrm{w} / \mathrm{v}) \mathrm{BSA}$ and $10 \mathrm{~mm} \mathrm{CaCl}_{2}$.

\section{HEPES-Sorbitol Buffer}

50 mм HEPES-KOH (pH 7.3)

$330 \mathrm{~mm}$ sorbitol

Percoll Gradient Buffer (40\%)

$40 \%$ (v/v) Percoll

50 mм HEPES-KOH (pH 7.3)

$330 \mathrm{~mm}$ sorbitol

$1 \mathrm{mM} \mathrm{MgCl}_{2}$

$1 \mathrm{~mm} \mathrm{MnCl}_{2}$

2 mм EDTA

Percoll Gradient Buffer (85\%)

85\% (v/v) Percoll

50 mм HEPES-KOH (pH 7.3)

$330 \mathrm{~mm}$ sorbitol 
W5 Solution for Protoplasts

2 mм 2-(N-morpholino)ethanesulfonic acid ( $\mathrm{pH}$ 5.7)

$154 \mathrm{~mm} \mathrm{NaCl}$

$125 \mathrm{~mm} \mathrm{CaCl}_{2}$

$5 \mathrm{~mm} \mathrm{KCl}$

\section{ACKNOWLEDGMENTS}

This work was supported by the Departments of Biology, University of Waterloo and Wilfrid Laurier University. M.D.S. and S.D.X.C. were supported by Natural Sciences and Engineering Research Council of Canada (NSERC) Discovery Grants.

\section{REFERENCES}

Cline K, Henry R. 1996. Import and routing of nucleus-encoded chloroplast proteins. Annu Rev Cell Dev Biol 12: 1-26.

Fitzpatrick LM, Keegstra K. 2001. A method for isolating a high yield of Arabidopsis chloroplasts capable of efficient import of precursor proteins. Plant J 27: 59-65.

Keeling PJ. 2004. Diversity and evolutionary history of plastids and their hosts. Am J Bot 91: 1481-1493.

Lung SC, Chuong SDX. 2012. A transit peptide-like sorting signal at the C-terminus directs the Bienertia sinuspersici preprotein receptor Toc159 to the chloroplast outer membrane. Plant Cell 24: 1560-1578.
Smith MD, Schnell DJ, Fitzpatrick L, Keegstra K. 2003. In vitro analysis of chloroplast protein import. Curr Protoc Cell Biol 17:11.16:11.16.1-11. 16.21.

Yoo SD, Cho YH, Sheen J. 2007. Arabidopsis mesophyll protoplasts: A versatile cell system for transient gene expression analysis. Nat Prot 2: $1565-1572$. 


\section{Isolation of Chloroplasts from Plant Protoplasts}

Shiu-Cheung Lung, Matthew D. Smith and Simon D.X. Chuong

Cold Spring Harb Protoc; doi: 10.1101/pdb.prot074559

\begin{tabular}{rc}
$\begin{array}{r}\text { Email Alerting } \\
\text { Service }\end{array}$ & Receive free email alerts when new articles cite this article - click here. \\
\hline $\begin{array}{c}\text { Subject } \\
\text { Categories }\end{array}$ & $\begin{array}{c}\text { Browse articles on similar topics from Cold Spring Harbor Protocols. } \\
\text { Cell Biology, general (1382 articles) } \\
\text { Plant (105 articles) } \\
\text { Plant Biology, general (118 articles) } \\
\text { Subcellular Fractionation (88 articles) }\end{array}$ \\
\hline
\end{tabular}

